Türk Turizm Araştırmaları Dergisi
2020,4(1):595-605.

\title{
Sosyal Pazarlama Kapsamında Konaklama İşletmelerinin Uyguladığı Çevre Duyarlı Uygulamalar: Kuşadası'ndaki 5 Yıldızlı Oteller Üzerinde Bir Araştırma*
}

Şafak TOPÇU, Yüksek Lisans Öğrencisi, Adnan Menderes Üniversitesi, Sosyal Bilimler Enstitüsü, Aydın, e-posta: safaktopcu@hotmail.com.tr

ORCID: https://orcid.org/0000-0003-2815-7520

Dr. Öğr. Üyesi Ahu YAZICI AYYILDIZ, Adnan Menderes Üniversitesi, Turizm Fakültesi, Aydın, e-posta: ayazici@adu.edu.tr

ORCID: https://orcid.org/0000-0002-1301-2428

Öz

Çağımızın en önemli sorunlarından biri çevre kirliliğidir. Çevre kirliliği, ulusal bir sorun olmaktan ziyade küresel bir sorun haline gelmiştir. Artık günümüzde ulusal ve uluslararası düzeyde çevrenin korunmasına ilişkin önlemler alınması gerektiği konusunda fikir birliği oluşmuştur. Bu konuda toplumsal duyarlılık gittikçe artmaktadır. En çok enerji tüketen sektörlerinden biri olan turizm sektöründe de çevresel konulara önem verilmesi gerekmektedir. Turizm ve çevre birbiriyle yakından ilişkisi olan kavramlardır. Turizmin sağlıklı bir şekilde yapılabilmesi için doğal, kültürel ve tarihi değerlere sahip çıkmamız gerekmektedir. Bu yüzden işletmelerin çoğu çevreye duyarlı uygulamaları yaygınlaştırarak çevreyi korumaya yönelik çalışmalar başlatmışlardır. Bu işletmelerin başında konaklama işletmeleri gelmektedir. Konaklama işletmeleri kullandığ kaynaklar neticesinde en çok tüketim yapan işletmelerdendir. Bu doğrultuda, çalışmada sosyal pazarlama kapsamında Kuşadası'nda bulunan 5 yıldızlı otellerin uyguladığı çevreye duyarlı uygulamalar araştırılmıştır. Çalışmanın amacı, otel işletmelerinin çevre duyarlılığına sahip olup olmadıklarını, çevre konusunda uyguladıkları uygulamaları ve beklentilerini öğrenmektir. Araştırmanın verileri yarı yapılandırılmış görüşme tekniği kullanılarak, toplam 10 otel yöneticisiyle görüşme yapılarak elde edilmiştir. Verilerin analizi için nitel araştırma analiz tekniklerinden betimsel analiz yöntemi kullanılmıştır. Çalışma sonuçlarına göre otellerde çevreye duyarlı uygulamalar yürütülmekte ve çevre bilincinin önemine yönelik eğitimler gerçekleşmektedir. Otel yöneticileri ile yapılan görüşmeler sonucunda, çevreye duyarlı uygulama yapan otel sayısının artması için devletin ve yerel yönetimlerin desteğinin artması gerekmektedir.

* III. Uluslararası EUREFE Kongresi'nde bildiri olarak sunulmuş ve özet olarak bildiri kitabında basılmıştır.

Anahtar Kelimeler: Çevre, Turizm, Sosyal Pazarlama, Konaklama İşletmeleri, Kuşadası.

Makale Gönderme Tarihi: 25.10.2019

Makale Kabul Tarihi: 13.01.2020

\section{Önerilen Atıf:}

Topçu, Ş. ve Yazıcı Ayyıldız, A. (2020). Sosyal Pazarlama Kapsamında Konaklama İşletmelerinin Uyguladığı Çevre Duyarlı Uygulamalar: Kuşadası'ndaki 5 Yıldızlı Oteller Üzerinde Bir Araştırma, Türk Turizm Araştırmaları Dergisi, 4(1): 595-605.

(C) 2020 Türk Turizm Araştırmaları Dergisi. 


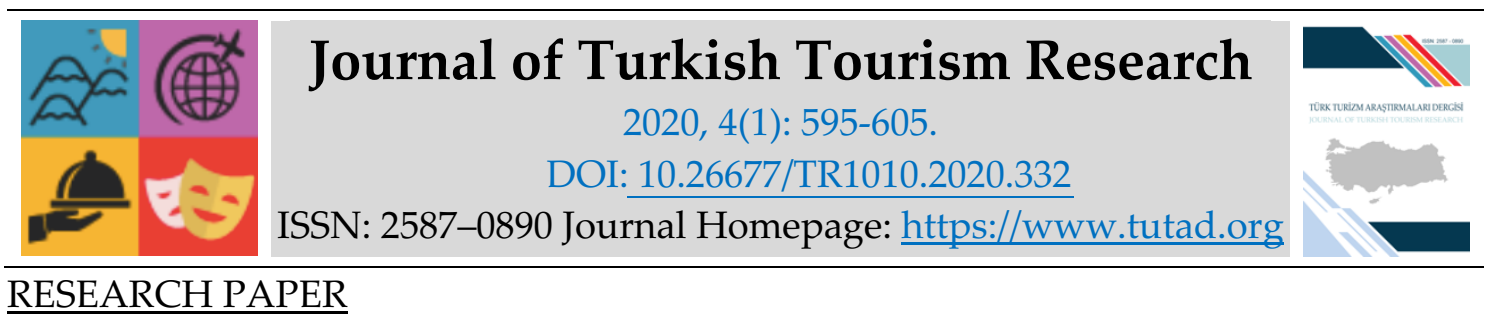

\title{
Environmentally Sensitive Practices Applied by Accommodation Companies in the Scope of Social Marketing: A Research On 5-Star Hotels in Kuşadası
}

Şafak TOPÇU, MSc. Student, Adnan Menderes University, Social Sciences Institute, Aydın, email: safaktopcu@hotmail.com.tr

ORCID: https://orcid.org/0000-0003-2815-7520

Assistant Prof. Dr. Ahu YAZICI AYYILDIZ, Adnan Menderes University, Faculty of Tourism, Aydın, e-mail: ayazici@adu.edu.tr

ORCID: https://orcid.org/0000-0002-1301-2428

\begin{abstract}
One of the most important problems of our age is environmental pollution. Environmental pollution has become a global problem rather than a national one. Nowadays, there is a consensus that national and international environmental protection measures should be taken. There is increasing social awareness in this regard. In the tourism sector, which is one of the most energy consuming sectors, environmental issues need to be given importance. Tourism and environment are closely related concepts. In order for tourism to be done in a healthy way, we need to protect natural, cultural and historical values. Therefore, most of the enterprises have started to work for protecting the environment by spreading environmentally sensitive practices. Accommodation businesses are at the top of these businesses. As a result of the resources it uses, accommodation enterprises are among the most consuming enterprises. In this context, within the scope of social marketing, environmentally sensitive practices applied by 5-star hotels in Kuşadası were investigated. The aim of this study is to find out whether the hotel establishments have environmental sensitivity, their applications and expectations about the environment. The data of the research were obtained by interviewing a total of 10 hotel managers by using semi-structured interview technique. Descriptive analysis method, one of the qualitative research analysis techniques, was used for data analysis. According to the results of the study, environmentally sensitive practices are carried out in the hotels and trainings are carried out for the importance of environmental awareness. With hotel managers as a result of the interviews, the support of the government and local administrations should be increased in order to increase the number of hotels that implement environmentally sensitive practices.
\end{abstract}

Keywords: Environment, Tourism, Social Marketing, Hospitality Industry, Kuşadası.

Received: 25.10 .2019

Accepted: 13.01 .2020

\section{Suggested Citation:}

Topçu, Ş. and Yazıcı Ayyıldız, A. (2020). Environmentally Sensitive Practices Applied by Accommodation Companies in the Scope of Social Marketing: A Research On 5-Star Hotels in Kuşadasi, Journal of Turkish Tourism Research, 4(1): 595-605.

(C) 2020 Türk Turizm Araştırmaları Dergisi. 


\section{GİRIŞ}

Günümüzde küresel ısınmanın beraberinde getirdiği olumsuz durumlar (su, hava, göl, deniz ve nehirlerin kirlenmesi, asit yağmurlarının neden olduğu orman ve bitki türlerinin yok olması, iklim değişikliği, ozon tabasında oluşan sorunlar gibi çevre sorunlarının artış göstermesine sebep olmuştur. Bundan dolayı tüm dünyada çevre dostu uygulamalara olan eğilim giderek artmaktadır. İşletmelerin bu bağlamda toplumsal duyarlılık için toplumun çıarına yönelik olarak uyguladıkları faaliyetler sosyal pazarlama anlayışı ile ilgilidir.

Sosyal pazarlama anlayışına göre, işletmelerin görevi; hedef pazarın istek ve ihtiyaçları ile birlikte ilgi alanlarını da belirleyip bunları rakiplere göre daha etkili ve etkin bir biçimde tatmin etmek ve bunu yaparken de tüketicilerin ve toplumun refahını korumaya ve yükseltmeye çalışmaktır (Kotler ve Roberto, 1989:17).

Çevre konusu turizm işletmelerini yakından ilgilendirmektedir. Çünkü turizm faaliyetleri doğal ve temiz bir çevreyi gerektirmektedir. Turizm faaliyetlerinin doğal çevreye zarar vermeyecek şekilde planlanıp uygulanması çok önemlidir. Bunu uygulaması gereken işletmelerin başında da konaklama işletmeleri gelmektedir. Değişen ve gelişen dünyada konaklama işletmeleri misafirlerin tutumlarını göz ardı edemezken misafirlerin çevresel sorunlara karşı bakış açıları ve bu konulara karşı hassasiyetlerini de dikkate almak zorundadırlar. Nitekim birçok turistin çevreye karşı duyarlı olan işletmeleri tercih etmesi bu konunun hassasiyetini göstermektedir.

$\mathrm{Bu}$ çalışmada sosyal pazarlama kapsamında konaklama işletmelerinin çevre duyarlı uygulamalarını ortaya koymak amaçlanmaktadır. Çalışmanın birinci bölümünde gerekli literatür bilgileri verilmiş, sosyal pazarlama kavramı, çevre duyarlı uygulamalar, konaklama işletmelerinde çevre duyarlı uygulamalardan bahsedilmiş, bulgular kısmında ise otel yöneticileri ile yapılan görüşme bilgilerine yer verilmiştir.

\section{SOSYAL PAZARLAMA KAVRAMI}

Sosyal pazarlama kavramı ilk kez 1970'li yıllarda Philip Kotler ve Gerald Zaltman öncülüğünde yapılmış çalışmalar neticesinde literatüre kazandırılmıştır (Eser ve Özdoğan, 2006:5; Kaplan, 2018: 8). Sosyal pazarlama, ticari amaçlara ek olarak sosyal açıdan topluma yararlı olacak duygu, düşünce ve hedeflerin pazarlanması sırasında pazarlamanın kavram ve yöntemlerine başvurarak gerekli faaliyetlerin üretilmesini içeren bir süreçtir (Kotler ve Roberto, 1989:24).

Sosyal pazarlama ile ilgili birçok tanıma yer verilse de genel olarak, toplumsal bir olgunun, hedef yahut ilkeleri belirlenen amaçlar doğrultusunda bireylerin sahiplenmesini hedeflemek amaciyla süregelen sürecin gelişim, uygula ve düzenli kontrolünün sağlanma süreci sosyal pazarlama olarak adlandırılmaktadır (Zikmund ve Damico, 1999:364). İşletmeler sosyal pazarlama bağlamında yapılan çalışmalar ile hem müşterilerini memnun eder hem de sosyal sorumluluk kapsamında üzerlerine düşen görevleri de yerine getirmiş sayılırlar (Sezer, 1999:53; Toker, 2007:37; Güleç, 2018:11;).

Yeni bilgilerin öğrenilmesi ve uygulamaların bilinirliğinin arttırılması, karşı pazarlama stratejisinin gerekli olduğu (zararlı alışkanlıklardan kurtarıp iyiye yönlendirmesi) durumlarda ve insanların yapmak isteyip de yapamadıkları şeyler için harekete geçirme amaçlı sosyal pazarlama kullanılmaktadır (Yılmaz, 2006:44).

Sosyal pazarlamanın başarıya ulaşması için Kotler ve Lee (2008) belli başlı ilkeler belirlemiştir. Bunlar; uygulanmış başarılı kampanyalardan faydalanmak, değişimi özümseyecek bireylere yönelik çalışma yapmak, tek hamlelik davranışların yapılmasını sağlamak, sosyal pazarlamada hedef kitleye yönelik gerçeklikleri kullanmak, hedefleri ve gerçekleri karşılaştırıp sonuçları 
değerlendirmek, belli bir amaca yönlendirilmiş davranışlar için mal ya da hizmet tanıtımı, maddi gerçeklik yansıtmayan davranışların oluşmasını sağlamak, ulaşılabilirlik, verilen mesajların eğlence içerikli olması, iletişim ve medya araçlarını etkin kullanımı, hedef kitle tutumuna karşı sözler almak (sözleşme kaydıyla), sonuçların sürekli kontrol edilip gerekli düzenlemelerin yapılmasıdır. Sosyal pazarlamanın etkin bir şekilde başarıya ulaşması için belirlenen bu ilkeler ışığında gerekli çalışmaların yapılması gerekmektedir.

\section{ÇEVRE DUYARLI UYGULAMALAR}

Çevre sorunları, 21.yüzyılın sonlarında başlayan giderek artış gösteren ve bu sorunlara karşı doğanın olumsuz yöndeki değişime yetememesi ile oluşan sorunlar bütünüdür. Çevre sorunları bu şekilde devam etmesi ve etkili bir önlem alınmaması sonucunda gelecek kuşaklara aktarılacak doğal çevreye dair herhangi bir unsurun olmayacağı söylenebilir (Baykal ve Baykal, 2008: 4).

Çevresel sorunlar neticesinde bilinçlenmek zorunda olan insanoğlu çevre duyarlı uygulamalar konusundaki gelişmelere açık olmak zorunda olduğu söylenebilir. Çevre duyarlı uygulamalar, genel itibari ile yeşil pazarlama kapsamında değerlendirilmektedir. Literatürde yeşil pazarlama tanımlanırken herhangi bir kurum kuruluş yahut işletmenin pazarlama aksiyonlarının doğayı koruma ve temiz çevrenin sürdürülebilirliği kapsayan süreçler bütünü olduğu söylenmiştir (Özata, 2006:1).

Çevrenin korunması hususunda başta turizm olmak üzere bütün sektörlerin devamlılı̆̆ını sağlayabilmesi konusunda alınması gereken hayati derece de önemli olan tedbirler mevcuttur (Pak, 2018:32). Çevrenin korunmasına yönelik çevre duyarlı uygulama önlemleri başlıca şunlardır; mavi bayrak, yeşil yıldız, beyaz yıldız, gren key, gren globe, greening hotel, ecotel, travelife, çevre fuyarlı işletme plaketleri, eko-label, ISO 14001. Bu uygulamalar sayesinde insanoğlu daha duyarlı bir toplum ve gelecek kuşakların bırakılan doğal mirasın sürdürülebilirliği konusunda belli başlı görevleri tamamlamış olacaktır (Gökdeniz, 2017: 72).

\section{KONAKLAMA ISŞLETMELERİNDE ÇEVRE DUYARLI UYGULAMALAR}

Çevre duyarlı işletmecilik kavramı ilk kez sürdürülebilir kalkınma adı altında düzenlenen Birleşmiş Milletler İnsan Çevresi Konferansının yapıldığı Stockholm’de 1970li yıllarda ortaya atılmıştır (Srivastava, 2018: 180). Zaman içerisinde yapılan konferans, toplantı ve etkinliklerde çevrenin sürdürülebilirliği konusuna dikkat çekmek amaçlanmıştır. Türkiye 1955 'de tarihinde bir ilk kez "Türkiye Tabiatını Koruma Derneği" ile konuya dikkat çekmiş, resmi düzeyde de üçüncü kalkınma planında konu hakkında detaylı işlemlere başlanılmıştır. Zaman içerisinde değişen düzenlemelerle konu önem kazanmış ve sürdürülebilir kalkınma kapsamında ulusal düzeyde ele alınmıştır (Podubnii, 2019: 9).

Çevreye karşı var olan duyarlılığın en üst düzeyde sağlanması için otel işletmeleri gerçekleştirdiği tüm faaliyetlerinde değerlendirme, ölçme, gözlem yapma, uygulama ve kontrol aşamalarını gerçekleştirmeyi hedeflemektedir. Konaklama işletmelerinin etkinliklerinin yer aldığı doğal çevre, ekolojik ortamının topluma yansıyan etkileri, bölgesel, ülkesel ve dünya çapındaki tesirleri araştırılmalıdır (Stabler ve Goodall 1997: 20).

Konaklama işletmelerinde çevreye yönelik yapılan koruma faaliyetleri genel itibari ile enerji, atık azalımı, su kaynaklarının korunup hava kalitesini arttırmaya yönelik uygulamalar olduğu söylenebilir. Konaklama işletmelerinin yapım aşamasında sürdürülebilir enerji kullanımına uygun, doğal kaynakları kullanmadan kendi kendine yetebilen bir yapı göre inşa edilmesi önerilmektedir. Bu yapıya uygun inşa edilmemiş işletmeler ise, çevre duyarlı uygulamalar 
kapsamında yapacakları yatırımlar kısa dönemde ek maliyet yaratsa da uzun dönemde ise kar, tüketimin azalması ve işletmenin imajına büyük oranda katkı sağlayıp işletmenin bilinirliğini ve karlılı̆̆ arttıracaktır (Ayala 1995: 351-353).

Konaklama işletmelerinde çevre duyarlı uygulamalar konusunda; işletme binasının dış cephe boyasının açık renklerle boyanıp oluşacak aşırı ısınmaların önlenmesi, kış aylarında ısı kaybını önlemek için uygun yerlerin cam duvarlarla çevrilmesi, yalıtım sistemlerinin uygulanması, yağmur suyunun biriktirilip sulama sistemlerinde kullanılması, güneş ışığından faydalanacak yere konumlandırılan pencereler, otelin güneş alan dış cephe alanında "kışın yaprak döken" ağaçlandırma çalışması yapılması, işletmenin çatısında ya da uygun yerlere güneş enerji panelleri kurulması, işletme çevresinin bitki örtüsü korunup harici müdahaleler önlenmeli, işletme de oluşan atık suların arıtılması ve bu suların sulama işlemlerinde kullanılması kapsamında gri su formatına dönüştürülmesi, organik ve gıda atıklarının birleştiren makine kullanılması, atıkların geri dönüşümü için gerekli işletmelerle iletişime geçilmesi, farklı çöp kutularıyla atıkların ayrıştırılması (Yusof ve Jamaludin, 2013: 428), gibi çabalar konaklama işletmelerinin sürdürülebilir çevre duyarlılığı kapsamında yerine getirebileceği önlemlerdir (Karadoğan ve Sakınç 2007: 41).

\section{ARAŞTIRMANIN AMACI VE YÖNTEMI}

Çevreye karşı duyarlı olan bireyler, çevreye karşı duyarlı bir tutum sergileyen işletmeleri tercih etmektedir. Bu yüzden konaklama işletmelerinin çevreye karşı duyarlı olması son derece önemlidir.

$\mathrm{Bu}$ araştırmanın amacı, sosyal pazarlama kapsamında Kuşadası'nda faaliyette bulunan 5 yıldızlı otel işletmelerinin çevre duyarlılığına sahip olup olmadıklarını, çevre konusunda uyguladıkları uygulamaları ve bu konuda ki beklentilerini öğrenmektir.

$\mathrm{Bu}$ araştırma, otel işletmelerinin uyguladığı çevre duyarlı uygulamaların diğer otel işletmelerine, farklı sektörde ki işletmelere ve topluma örnek teşkil etmesi bakımından önem arz etmektedir. Araştırma evrenini Kuşadası'nda faaliyette bulunan 5 yıldızlı otel işletmeleri oluşturmaktadır. Araştırma verileri yarı yapılandırılmış görüşme tekniği kullanılarak, toplam 10 otel yöneticisiyle görüşme yapılarak elde edilmiştir. Araştırmada nitel yöntemden yararlanılmasının nedeni, araştırmanın konusu ve amacının buna uygun olması, yönetici konumundaki kişilerin görüşlerinin nicel yöntemle elde edilmesinin zorluğu, araştırmaya dahil edilen otel işletmelerinin sınırlı olmasıdır. Bu araştırmada veri toplama aracı olarak görüşme tekniğinin kullanılmasının temel nedenlerinden biri görüşmeciye görüşülen kişinin konu ile ilgili görüşlerinin derinlemesine elde etmesine olanak vermesidir. Araştırmada kullanılan görüşme formu Molla (2016), Otel İşletmelerinde Yöneticilerin Çevre Yönetiminden Algıladıkları Faydanın Çevreye Duyarlı Uygulamalara Yönelmelerinin Değerlendirilmesi, Mercan (2018), Otel İşletmeleri Çevre Uygulamalarının AB Çevre Uygulamaları Kapsamında Değerlendirilmesi: 5 Yıldızlı Zincir Oteller Üzerine Bir Araştırma, Yıldırım (2019), İstanbul'da Beş Yıldızlı Otellerde Yeşil Yıldız Uygulamasının Otellerin İşletmeciliğine Sağladığı Avantajların Analizi başlıklı çalışmalarından yararlanılarak oluşturulmuştur. Araştırma kapsamında 10 yönetici ile görüşme yapılmıştır. Görüşmeler 01.08.2019-20.09.2019 tarihleri arasında önceden otel yöneticilerinden randevu alınarak gerçekleştirilmiştir. Görüşmeler sırasında yöneticilerin sorulara yönelik cevapları yöneticilerin izniyle not alınmıştır. Verilerin analizi için nitel araştırma analiz tekniklerinden betimsel analiz yöntemi kullanılmıştır. 


\section{BULGULAR}

Görüşülen otellerin görüşlerine yer verilen bu bölümde görüşmecilere kod adı verilerek veriler açıklanmaya çalışılmıştır. Birinci otelin yöneticisi Katılımcı 1 (K1) olacak şekilde bilgiler aktarılmıştır. Görüşme yapılan kişiler ile ilgili cinsiyet, eğitim durumu, yaş, çalıştıkları departman gibi genel bilgilere ilişkin tablo aşağıda verilmiştir.

Tablo1. Görüşme Yapılan Kişilerin Demografik Özellikleri

\begin{tabular}{|l|l|l|l|l|}
\hline Kişi & Departman & Eğitim Durumu & Cinsiyet & Yaş \\
\hline K1 & Misafir İlişkileri Müdürü & Lisans & Kadın & 47 \\
\hline K2 & Gida Mühendisi & Lisans & Kadın & 35 \\
\hline K3 & Teknik Servis Şefi & Lise & Erkek & 48 \\
\hline K4 & Kalite Müdürü & Lisans & Erkek & 38 \\
\hline K5 & Kalite Müdürü & Lisans & Kadın & - \\
\hline K6 & Gida Mühendisi & Lisans & Kadın & 34 \\
\hline K7 & Kalite Mühendisi & Lisans & Kadın & 23 \\
\hline K8 & Gida Kalite Kontrol & Lisans & Kadın & 30 \\
\hline K9 & Yalın Yönetim Sistemleri Yöneticisi & Lisans & Kadın & 43 \\
\hline K10 & Gida Mühendisi & Lisans & Kadın & 25 \\
\hline
\end{tabular}

Araştırmaya katılan yöneticilerin çevre kirliliğinin sebebine ilişkin görüşleri tabloda verilmiştir.

Tablo 2. Çevre Kirliliğinin Nedenlerine İlişkin Bulgular

\begin{tabular}{|l|l|}
\hline K1 & İnsanlar \\
\hline K2 & Kanalizasyon atıkları \\
\hline K3 & Sanayi atıkları \\
\hline K4 & İnsanlar \\
\hline K5 & Bilinçsiz insanlar \\
\hline K6 & İnsanların duyarsızlığı ve eğitimsizliği \\
\hline K7 & Bilinçsiz insanlar \\
\hline K8 & İnsanlar \\
\hline K9 & Toplumun eğitim eksikliği \\
\hline K10 & İnsanların konu hakkındaki duyarsızlı̆̆1 \\
\hline
\end{tabular}

İşletme olarak çevre duyarlılığı sizin için neyi ifade eder? sorusuna genel olarak temiz çevre, temiz ortam, sürdürülebilir turizm, sürdürülebilir çevre ve çevrenin korunması şeklinde yanıt verilmiştir. Katılımcı 8; atıkların ayrıştırılması, enerji kaynaklarının tasarrufu, atık yağ prosedürü uygulaması şeklinde yanıt verirken, Katılımcı 9; kaynakları etkin kullanmayı, doğal yaşamla mücadele etmeyi, sürdürülebilir çevre/dünya için çevreyi kullanmayı, çevre sorunlarının çözümünün bir parçası olmayı, çevre değerlerini korumaya aktif olarak katılmayı ifade eder şeklinde yanit vermiştir.

İşletmenizin herhangi bir uluslararası çevre yönetim sertifikası var mıdır? Çevresel sertifika almaya başvurmanızın temel sebeplerini anlatabilir misiniz? Neden böyle bir sertifika almaya gereksinim duydunuz? sorusuna katılımcıların çoğunluğu sertifika alma sebeplerini misafirleri bilgilendirmek, prestij sahibi olmak, rekabet ortamında pazarlama aracı olarak kullanmak ve toplumsal sorumluluğu yerine getirmek olarak yanıtlamışlardır. Katılımcı 9; İSO 14001 Çevre Yönetim Sistemi, Mavi Bayrak, Yeşil Yıldız, Yeşil Anahtar, Travelife sertifikaları olduğu 
belirtirken, Katılımcı 1 ise, İSO 14001 Çevre Yönetim Sistemi, 9001 Çevre Yönetim Sistemi ve 22000 Gıda Güvenliği Yönetim Sistemi sertifikalarına sahip olduklarını, sertifikaları pazarlama aracı olarak kullandıklarını ifade etmiştir. Katılımcı 3 ise, Mavi Bayrak sertifikasına sahip olduklarını, bu sertifikanın turistlerin otel tercihinde çok önemli olduğunu vurgulamıştır. Katılımcı 8 ise, çevre yönetim sertifikasına sahip olmadıklarını ama almak için hazırlık yaptıkların belirtmiştir. "Misafir memnuniyeti, çeoremize karşı duyarlı olabilmek, gelecek nesillere temiz çevre bırakabilmek amacıyla bu sertifikaları edinmek istiyoruz. Aynı zamanda bu sertifikalar işletme açısından pazarlama aracı olarak da kullanılacaktır" ifadelerini kullanmıştır.

Tesiste çevre etiketli eşyaları kullanmayı tercih ediyor musunuz? Eko etiketli ürünler hakkındaki düşünceleriniz nelerdir? Bu ürünlerin otelde kullanım durumundan bahseder misiniz? sorusuna Katılımcı 1, işletmede kullanımının tercih edildiğini belirtmiştir. Eko etiketli ürünleri kullanma sebeplerinin ise genel olarak çevre duyarlılığına katkı sağlamak, çevreyi korumak ve sürdürülebilir bir turizm yaratmak gibi nedenlerle yapıldığını ifade etmiştir. Katılımcı 2, eko etiketli parlatıcılar, yumuşatıcılar kullandıklarını, Katılımcı 3, tasarruflu ampuller, led ampuller, temiz içerikli temizlik maddeleri kullandıklarını, Katılımcı 6, daha az elektrik tüketimi yapan aletler tercih ettiklerini, Katılımcı 7, plastik bardak, çatal, kaşıt, poşet gibi tek kullanımlık üründen kaçındıklarını, led ampuller gibi tasarruflu ürünler kullanılmaya çalıştıklarını, Katılımcı 9, özellikle düşük enerjili elektrikli ekipmanlar kullandıklarını belirtmiştir. Katılımcı 6, "Eko etiketli ürünler çok maliyetli olduğu için çok fazla yönelemiyoruz", Katılımcı 8, "Çevre etiketli eşyaları kullanmayı tabi ki de tercih ediyoruz. Boyalarda, gıdalarda, birçok üründe tercih ediyoruz. Ama şunu da belirtmeliyim ki eko etiketli ürünler eşittir maliyet. Bu gerçeği atlamamak gerek. Maliyet açısından eko etiketli ürünler gerçekten birçok kişiye ya da işletmeye sorun oluşturabileceğinden dolayı maalesef tercih edilmiyor" vurgularını yapmışlardır.

İşletmenizde enerji ve su kullanımına yönelik hangi uygulamalar yapılmaktadır? sorusuna, katılımcılar genel olarak güneş enerjisi panelleri ve su tasarrufu için perlatör kullanıldığını, su arıtmada ozmos kullanıldığını belirtmişlerdir. Katılımcı 9 ise, su kullanımına yönelik atık suların arıtıldıktan sonra bahçe sulama alanlarında kullanıldığını ve susuz pisuvarlar, duş ve lavabolarda perlatör kullanıldığını belirtmiştir. Katılımcı 8, "Bu konuda şöyle bir uygulamamız var. Odada misafir yokken klimaların çalışmamasını sağlıyoruz. Böylece tasarrufa gidiyoruz. Boşa elektrik tüketilmemiş oluyor. Ayrıca kimyasalların kullanımın en düşük seviyeye indirilmesi ve güneş enerji paneli kurulması yönünde çalışmalarımız var. Katılımcı 9, A plus düşük enerji tüketen ekipmanlar, led ampül kullanımı, odalarda switch kullanımı, tüm ortak alanlarda ve misafir odalarında konuya ilişkin bilgilendirme yazıları bulundurmak, günlük, haftalık, aylık kullanılan enerjinin takip edilmesi, su kullanımına yönelik, atık sular arıtıldıktan sonra bahçe sulama alanlarında kullanılması, susuz pisuvarlar, duş ve lavabolarda perlatör kullanmak gibi uygulamaları olduklarından bahsetmiştir.

Uyguladığınız çevre politikalarının ve uygulamalarının misafirlere duyurumunu yapıyor musunuz? Misafirlerinizi çevre politikalarınıza nasıl dahil ediyorsunuz? sorusuna tüm katılımcılar misafirlere bu konu hakkında bilgi verildiği yönünde yanıt vermişlerdir. Katılımcı 8, misafir otele girdiğinde, katlarda, asansörlerde, merdivenlerde, odalarda ve genel alanlarda çevre ile ilgili duyurular asılıp, çevreye duyarlılıkla ilgili yazılar yayınlanmaktadır ifadesini kullanmıştır. Katılımcı 10, "Misafire girişte verilen broşürlerde ilgili bilgilendirmeler bulunmaktadır. Ayrıca misafir alanlarına görsel materyaller ile farkındalık çalışması yapılmıştır." Katılımcı 5, "Misafiri dahil etmezsek bir anlamı kalmıyor. Odalarda su ve atıklar konusunda duyurular düzenli bir şekilde yapilyyor. Ortak alanlarda ve mini barlarda bulunan panolarda asil duyurular var. Ayrica personele plastik geri dönüşüm konusunda da bilgilendirme yapıllyor."

Atık yönetimi konusunda hangi uygulamaları yapmaktasınız? sorusuna tüm katılımcılar atıkların ayrıştırıldığı vurgusunu yapmışlardır. Katılımcı 3, "Pil atıkları Bursa'da bulunan bir 
firmaya gönderiliyor, diğer atıklar belediye ile işbirliği içinde geri dönüşüme veriliyor, ampul atıkları ise, ayrı bir firmaya veriliyor." Katılımcı 9, atıkları yerinde ayrıştırdıklarını, tehlikeli atıkların geri dönüşüme gönderdiklerini, e-atıkların lisanslı firmalara gönderdiklerini, büfeden geri dönen ürünlerin ölçüldügünü ve bütün atıkların türüne göre ayrıştırıldığını belirtmiştir. Katılımcı 7 ve Katılımcı 10 ise, büfeden dönen yemek artıklarının barınaklara gönderildiğini ifade etmiştir. Katılımc 10, "Tesis geneli atıkların düzgün ayrıştırılması için personel eğitimi veriliyor, ayrıştırılan atıklar çevre kanunu gereği lisansh firmalara teslim edilmektedir, ayrıca büfeden dönen yemek artıkları barnnaklara gönderilmektedir."

Tablo 3. İşletmede Çevre Politikası Konusunda Yapılan Uygulamaların Kimler Tarafından Uygulandığına ilişkin Bulgular

\begin{tabular}{|l|l|}
\hline K1 & Kalite Yönetim Görevlisi tarafından uygulanıyor. \\
\hline K2 & $\begin{array}{l}\text { Kalite Birimi tarafından uygulanıyor, çevre danışman firmasından ayrıca destek } \\
\text { sağlanıyor. }\end{array}$ \\
\hline K3 & Çevre Mühendisi tarafından uygulanıyor. \\
\hline K4 & Tüm personel ve misafir tarafından uygulanıyor. \\
\hline K5 & Otel yönetimi ve tüm otel personeli tarafından uygulanıyor. \\
\hline K6 & Kalite müdürü tarafından uygulanıyor. \\
\hline K7 & Kalite mühendisleri tarafından uygulanıyor. \\
\hline K8 & Gida mühendisi tarafından uygulanıyor. \\
\hline K9 & Teknik müdür ve kalite müdürü tarafından uygulanıyor. \\
\hline K10 & Otelin tüm personeli ve yöneticileri tarafından uygulanıyor. \\
\hline
\end{tabular}

Otelinizde personelin çevre konusunda bilinçlenmesi ve uygulamaları benimsemesi için ne tür çalışmalar yapılıyor? sorusuna tüm katılımcılar bu konuda tüm otel personeline eğitim verildiği yanıtını vermişlerdir. Katılımc1 3, yılda 3 kez eğitim verildiğini belirtirken, Katılımcı 4 ise, her ay düzenli eğitim verildiğini belirtmiştir. Katılımcı 9 ise, personel eğitiminde dış kaynaklardan da faydalanıldı̆̆ını belirtmiştir.

Tablo 4. Çevresel Uygulamaların Otel İşletmesine Olan Katkılarına İlişkin Bulgular

\begin{tabular}{|l|l|}
\hline K1 & Müşteri memnuniyetini artırması, işletmenin pazar payının büyümesi \\
\hline K2 & $\begin{array}{l}\text { İşletmenin pazar payını artırması, misafir memnuniyetini artırması, rekabet } \\
\text { gücünü artırması. }\end{array}$ \\
\hline K3 & Devlet desteğinden yararlanıp, pazar payını artırması. \\
\hline K4 & Olumlu imaj sağlaması. \\
\hline K5 & İşletmeye tasarruf sağlaması, müşteri memnuniyeti ve rekabet avantajı sağlaması. \\
\hline K6 & $\begin{array}{l}\text { Rekabet avantajı ve misafir memnuniyeti sağlaması, devlet desteği sayesinde daha } \\
\text { çok yatırım yapma imkanına destek vermesi. }\end{array}$ \\
\hline K7 & Müşteri memnuniyeti sağlaması \\
\hline K8 & $\begin{array}{l}\text { Pazar payının yükselmesi, müşteri memnuniyetinin sağlanması ve işletme olarak } \\
\text { da gelişim göstermemize destek vermesi. }\end{array}$ \\
\hline K9 & Rakiplerden ayrılıp, fark yaratmamızı sağlaması. \\
\hline K10 & Kaliteyi artırarak, misafir memnuniyeti sağlaması. \\
\hline
\end{tabular}


Çevre politikalarınız açısından çeşitli kişi ve kuruluşlardan beklentileriniz nelerdir? sorusuna;

Katılımcı 1, "Çevre Yönetim Sistemi belgesinin alımı ucuz olmalı, kamu kurumlarından buna yönelik bir çalışma yapılmasını bekleriz. Sayıca ülkemizde bu kuruluşlar az, yeterli değil. Bu konularda da çalışmalar yapılması gerektiğini düşünüyorum."

Katılımcı 4, "Belediye ile iş birliği yapılmasını, belediyenin bu konuda çalışmalar yapmasını isteriz. Diğgr otellerle birlikte çalışmalar yaparak okullarda eğitim vermenin faydah olacağını düşünüyorum."

Katılımcı 5, "Diğger otel işletmeleriyle birlikte projeler yapılmasını isteriz. Diğer otellerle yapılacak etkinliklerin faydalı olacağını düşünüyorum. Birlikte çalışılması gereken konular var. Bu konularda bencil olmanın çevreye bir faydası yok. Herkes bu ülkede yaşıyorsa, bu bölgede nefes alıyorsa, elimizi taşın altına koymalıyız. Koyar gibi yapmadan elimizi taşın altına koymalıyız. Yapılacak olan proje, faaliyet için birlikte organize olmaliyı."

Katılımcı 7, "Yoğun sezonda atık konusunda belediyeden yeterli destek alamıyoruz. Bu konuda belediyeden destek bekliyoruz. Diğer otellerle birlikte çalışmalar yapılması gerektiğini düşünüyorum. Sıfır atık için reklam ve bilinçlendirme gibi aksiyonlar başlatılmalıdır."

Katılımcı 8, "Orman Bakanlığının ağaç dikmesini istiyoruz. Belediyeler bu konuda bizlere yer göstermiyorlar."

Katılımcı 9, "Yerel idarelerin çok daha aktif çalışması, yerel idare ve özel idarelerin ortak çalı̧malarının arttırlması, altyap yetersizliklerinin giderilmesi (arıtma), atıklarn teslim edebilecek lisansl firmalarm arttırlması (cam atıklar, bio atıklar) beklentilerimiz arasında, atıkları verebilecek yer bulamıyoruz, bu konuda çok büyük sıkıntılar yaşıyoruz."

Sektörde ki tüm paydaşlar arasında gerekli işbirliği yapılırsa ve yerel yönetimler ihtiyaç duyulan desteği sağlarsa çevre konusunda daha bilinçli ve sürdürülebilir adımlar atılabilir.

\section{SONUÇ VE ÖNERİLER}

Gün geçtikçe artan çevre bilinci ve duyarlılığı sonucunda sadece çevre koruması uygulamalarının yapılıp yapılmadığı değil aynı zamanda bu uygulamaların sürdürülebilirliği de önem arz etmeye başlamıştır. Özellikle turizm işletmelerinin ve konaklama işletmelerinin varlıklarını devam ettirmesi açısından bu kavram daha da önemlidir. Doğaya sahip çıkmadan ve korumadan sürdürülebilir bir turizmden bahsetmek mümkün değildir. Günümüzde işletmeler çevresel duyarlılığı ön planda tutan çalışmalar yapmak zorundadır. Devlet baskısı, misafir beklentileri ve bunun rekabet avantajı sağlaması, maliyet ve tasarruf sağlaması gibi birçok nedenden dolayı otel işletmelerinde yeşil pazarlama uygulamalarının arttığı ortaya çıkmıştır.

Bu çalışmada sosyal pazarlama kapsamında Kuşadası'nda bulunan 5 yıldızlı otellerin uyguladığı çevreye duyarlı uygulamalar araştırılmıştır. Çalışmanın sonuçlarına göre, otellerde çevreyle ilgili uygulamalar genellikle teknik servis çalışanları ve gıda mühendisleri tarafından yürütülmektedir. Otellerde çevre kirliliğine en başta bilinçsiz insanların neden olduğu ortaya çıkmıştır. Görüşme yapılan otellerin çevre konusunda gerekli belgelere sahip olduğu, eksikler için de başvuru yaptıkları belirlenmiştir. Ayrıca otel yöneticileri, çevreye duyarlı uygulamalar yaparken yerel yönetimlerden ve diğer kuruluşlardan yeterli desteğin gelmediğini ifade etmişlerdir.

Sürdürülebilir bir çevre için çevre duyarlı uygulamaların geliştirilip uygulanması gerekmektedir. Bu konuda bazı önerilerde bulunulmuştur. Bu öneriler; 
- Sürdürülebilir çevre için işletmeler belirli maliyetleri göze almalıdır. Sürdürülebilir çevrenin oluşturulması için günü kurtarmanın ötesine geçilmesi hem çalışan hem de misafirlerin yönelik eğitim çalışmaları yapılarak bilinçlendirmesi gerekmektedir. Eğitimler esnasında çalışanlar ve misafirler sürece dahil edilmelidir. İyi uygulama örnekleri baz alınarak işletme kapsamında gelişim sağlanmalıdır.

- İşletmelerde kalite birimi kurulması gerekmektedir. Kalite biriminin bir kolu olarak çevre mühendisi ya da alanında eğitim almış yetkili kişi tarafından bütün uygulamaların sıkı biçimde denetimden geçmesi gerekmektedir.

- İşletmeler atıkların yerinde ayrıştırmasını sağlamalıdır.

- İşletmeler gıda atıklarının organik gübreye dönüştürmeli, gıda atığını azaltmak adına Kompost makinesi kullanarak doğal çevreye zararının minimum düzeye indirilmesini sağlamalıdır.

- Tekstil atıklarını geri dönüşüm kapsamına alıp, lisanslı firmalarla anlaşmalar yaparak geri dönüşümü sağlanmalı ve işletme bünyesinde yeniden kullanılabilir hale getirilmelidir.

- Atık ayrıştırma konusunda misafirlere bilgi verilip, otel koridorlarına atık ayrıştırma kutuları konmalıdır.

- Odalardaki enerji tüketimini azaltmak için tasarruf sistemleri geliştirilmeli, akıllı oda kavramı dikkate alınarak uygulanmalıdır.

- Gıda atıklarını değerlendirilerek hayvan barınağına verilmesi hususunda belediye ile işbirliği yapılmalıdır.

- Arıtma sistemi olmayan işletmelerin bir an önce bu sistemi kurması gerekmektedir.

- Bölge olarak güneşli gün sayısını çok olmasını avantajına çevirip güneş enerji panellerinin yaygın bir şekilde kullanılması ve otel içerinde enerji tüketen cihazların düşük enerjili olanların tercih edilmesi gerekmektedir.

- Gri su (Yağmur Suyu) ve deniz suyundan içme suyu elde edilecek sistemin kurulması önerilebilir.

- Belediyelerin işletmelerle olan iş birliği geliştirilmelidir. Atıkların toplanması ve atık kutuların temini konusunda ortak çalışmalar yapılmalıdır.

- Yerel halkın çevre duyarlı uygulamalar konusunda bilinçlendirilmesi adına çalışma başlatmalıdır.

- Denetim yapan özel çevre danışmanlık firmaların devlet tarafından denetlenmesi gerekmektedir.

\section{KAYNAKÇA}

Ayala, H. (1995). Ecoresort: a Green Master Plan For The International Resortin Industry. International Journal of Hospitality Management, 14.3.

Baykal, H. ve Baykal, T. (2008). Küreselleşen Dünya'da Çevre Sorunları. Mustafa Kemal Üniversitesi Sosyal Bilimler Enstitüsü Dergisi, 5 (9), 2-17.

Eser, Z. ve Özdoğan, F. B. (2006). Sosyal Pazarlama. Ankara: Siyasal Kitabevi.

Gökdeniz, A. (2017). Konaklama Sektöründe Yeşil Yönetim Kavramı, Eko Etiket ve Yeşil Yönetim Sertifikaları ve Otellerde Yeşil Yönetim Uygulama Örnekleri. Uluslararası Sosyal ve Ekonomik Bilimler Dergisi, (2), 54-61.

Güleç, V. (2018). Sosyal Pazarlama Kampanyalarında Kamu Spotu Kullanımının İncelenmesi: Sigarayı Bırak-Hayatı Bırakma Kampanyası. Yüksek Lisans Tezi. İstanbul Aydın Üniversitesi Sosyal Bilimleri Enstitüsü, İstanbul. 
Karadoğan, H. ve Sakınç, M. (2007). İstanbul Teknik Üniversitesi Eko- Yapı Projesi, Yapı Dergisi Ekolojik Tasartm ve Sürdürülebilirlik Eki, 2007.

Kaplan, M. (2018). Sosyal Pazarlama Faaliyetlerinin Gönüllülük Davranışlarına Etkisi: Türk Kızılay'ı ve Kan Bağışı Üzerine Bir Araştırma, Yüksek Lisans Tezi.

Kotler, P. ve Lee, N. R. (2008). Kurumsal Sosyal Sorumluluk, Sibel Kaçamak (Çev.), İstanbul: MediaCat Kitapları,

Kotler P. and Roberto, L.E. (1989). Social Marketing: Strategies for Chancing Public Behavior, Collier Macmillan Publishers, London.

Molla, A. (2016). Otel İşletmelerinde Yöneticilerin Çevre Yönetiminden Algıladıkları Faydanın Çevreye Duyarlı Uygulamalara Yönelmelerinin Değerlendirilmesi, Çanakkale Onsekiz Mart Üniversitesi, Sosyal Bilimler Enstitüsü Turizm İşletmeciliği Anabilim Dalı, Çanakkale.

Özata, Z. (2006). Yeşil Pazarlama. 12 Eylül 2019 tarihinde https://zeynepozata.wordpress.com/2006/05/10/yesil-pazarlama/ adresinden alınmıştır.

Pak, A. (2018). Otel İşletmeleri Çevre Uygulamalarının Ab Çevre Uygulamaları Kapsamında Değerlendirilmesi: Yıldızlı Zincir Oteller Üzerine Bir Araştırma. Yüksek Lisans Tezi, Çanakkale Onsekiz Mart Üniversitesi Sosyal Bilimler Enstitüsü Turizm İşletmeciliği Anabilim Dalı, Çanakkale.

Podubnii, M. (2019). Otel İşletmelerinin Çevreye Duyarlı Rekabet Stratejileri ile Dinamik Yeteneklerinin Rekabet Üstünlüğü Açısından İncelenmesi. Yüksek Lisans Tezi. Akdeniz Üniversitesi Sosyal Bilimler Enstitüsü, Antalya.

Sezer, İ. (1999). Sosyal Pazarlama ve Türkiye Uygulamaları. Erciyes Üniversitesi İktisadi ve İdari Bilimler Fakültesi Dergisi, 14.

Srivastava, A. (2018). The Principle of Sustainable Development: International and National Perspectives. Contemporary Issues in International Law, 180.

Stabler, M, and Goodall, B. (1997). Environmental awareness. Action and Performance in The Guernsey Hospitality Sector, Tourism Management, 18(1): 19-32.

Toker, B. (2007). İşletmelerde Sosyal Pazarlama Faaliyetlerinin Performansa ve Marka Bilinirliğine Etkileri Üzerine Bir Araştırma. Yüksek Lisans Tezi. Selçuk Üniversitesi Sosyal Bilimler Enstitüsü, Konya.

Yılmaz, D. (2006). Sosyal Pazarlama Anlayışı ve Bir Uygulama. Yüksek Lisans Tezi. Marmara Üniversitesi Sosyal Bilimler Enstitüsü İşletme Anabilim Dalı Üretim Yönetimi ve Pazarlama Bilim Dall, İstanbul.

Yıldırım, Ö. (2019). İstanbul'da Beş Yıldızlı Otellerde Yeşil Yıldız Uygulamasının Otellerin İşletmeciliğine Sağladığı Avantajların Analizi, İstanbul Ticaret Üniversitesi, Sosyal Bilimler Enstitüsü Turizm İşletmeciliği Anabilim Dalı, İstanbul.

Yusof, Z. B. and Jamaludin, M. (2013). Green Approaches of Malaysian Green Hotels and Resorts. Procedia - Social and Behavioral Sciences, 85: $421-431$.

Zikmund, W. and Damico, M. (1999). Marketing. Cincinnati: South-Western College Publishing, 6th edition. 